\title{
Hegel's Ideas on Education in the Philosophy of Right -- from the perspective of historical materialism
}

\author{
Yingxue Xu \\ College of Liberal Arts and Sciences, University of Defense and Technology, Changsha 410073, \\ China \\ xuyingxuexx@163.com
}

Keywords: historical materialism, Hegel, education, Philosophy of Right.

\begin{abstract}
In Hegel's Philosophy of Right, the necessity of education for men have been mentioned frequently. It is believed by Hegel that education, through which the development from origin to nature would be completed, is the key to freedom of mind by liberate people from his nature state. By looking into statements related to education in Hegel's Philosophy of Right in perspective of Marxist historical materialism, the study found that even though Hegel has answer the questions of "what education is", "why to educate" and "how to educate", he has missed the material basis of mind. Hegel's ideas on education has shown, in Marx's words, conservative political opinion and idealism, which becomes the theoretical foundation for ruling class.
\end{abstract}

\section{Introduction}

Recent Chinese studies on Hegel's education ideas are mostly concentrated on the significance of education in forming Spirit or in ethical life, however, they all neglect the education, which to make men ethical, is built on current ideology of the state. Therefore, education is easy to be used as a tool for ideological unity. Education mentioned by Hegel has a very explicit goal, which would never change with era. Obviously, this is contradicted to historical materialism. Re-discovering Hegel's ideas on education from Marxism would deepen the understanding and practice of Marxist historical materialism.

\section{Nature of Education: a Directive Work to Mind}

\subsection{Education as a "Liberator"}

Marxist historical materialism holds that cognition and consciousness are the product of material production, which is to say a certain social development is equipped with corresponding ideas. While Hegel turns his back on this basis, and tries to liberate people's mind directly. "The final purpose of education, therefore, is liberation and the struggle for a higher liberation still [1]."

Prison appears before liberation. By prison of mind, Hegel means the existing thinking status of the public. He believes that people in society has mistaken state of nature as freedom. This unreal pursuing is only the way they use only the means which the accidents of nature directly assured to him to satisfy the so-called simple natural need. Before getting educated, people are only concentrated on the self-need, while this statue shows that the mental is plunged in the natural and so would be one of savagery and unfreedom [2], and it also criticized by Hegel as a mere force against ethical life, which represents a state of affairs where mere force prevails[3]. To support, Hegel take an example of English-style of [comfortable]. He pointed out that every time the unreal comfortable condition exists, a new "uncomfortable" would follow the step, which becomes an inextricable circulation.

Hegel believes that only the educated people could get rid of suppress of original status, for liberating impact of education not only worked in form but also in the deep of mind. When educating, Spirit begins to rethink itself and reflect realistic world. This differs educated mind from primeval one. Education, as a liberation, would make great contribution to oppose and restrain an uncivilized will brought by merely natural will and to protect the implicit Idea of freedom. This is the noble mission of education endowed by Hegel. 


\subsection{Education as a "Culturist"}

Hegel believes that the influence of education would only be shown in the new habits of thinking. Finally, education makes the spirit into daily habits, in which the clash between the natural and the subjective will disappears, the subject's internal struggle dies away [4]. For example, ethic habit formed during education would replace original mere consciousness, therefore, a second nature, which was strange and rejected as external disturbance turns into the soul of custom permeating it through and through[5].

Theoretical education is responsible to thinking habit while practical education is responsible to the acting one. On the one hand, theoretical education is developed on the multiplicity of objects and situations of excite interest. This education consists a flexibility and rapidly of mind, ability to pass from one idea to another, to grasp complex and general relations, and so on [6]. In this way, it discovers people's new thinking habit. On the other hand, practical education is just education in the need and habit of being busy by pushing people to do work in their life. Labor, as a main method of satisfying people's need, also plays an important role in practical education. The automatically recurrent need for something to do, objective activity as well as the habit of universally recognized aptitudes would be gained naturally through labor, so that people's action would adopt to the nature of material and the pleasure of other workers.

\subsection{Education as a "Transformer"}

Hegel takes education as a bridge from realistic starting point to ideal end-point in order to promote mind development by mere subjectivity. However, due to the lake of law of the physical world, the supposed promoting effect has become incondite guidance of people. Hegel pointed out that nature of spirit doubtlessly exists. Only by education can people finally realize the meaning of freedom and then make an ethical substantiality true. Primary value of education is to drive the travel from to savagery to nature. In other words, education shows the savage their second birth, and transform his instinctive nature to intellectual natural. Instinctive natural, as a starting-point of mind development, representing the thinking status of most current people. But before he asserts that the status is fake, false and meager, Hegel does not take social reality together with existing ideas; Intellectual natural, which means the nature of human, is the destination. It exist at the very beginning of the world, but only the other world created by Hegel. At the same time, education would also transfer "thinking" to "acting". Actuality in substantial will is the complete and mature self-consciousness. Purpose of education is to transform the inherent to realistic, which reflects in life and social activities. The educated man can divine something of the nature and mind, learn the law of idea and gain consciousness of itself.

In Hegel's opinion, mind cannot develop by itself even though the mind is in itself. Education is the trigger. Uneducated people even can't realize their own needs, therefore their rational will. "To know what one wills, and still more to know what the absolute will, Reason, wills, is the fruit of profound apprehension and insight, precisely the things which are not popular [7]." Thus outside force, for example "force" from educator, is required for building profound apprehension and insight. While this force is not a violence because an educated man would not be coerced unless he is willing to. So it would be called "transformer". By taking education in different phases, fields and directions, people become members of classes or groups, and interact in society. Civilization continues in this way.

\section{Mission of Education: Development of Individuals Mind}

\subsection{Realizing True Freedom}

Freedom is the nature of all the ideological contents including ethic, will and the good. Based on people pursuing for freedom, Hegel divided it into abstract freedom and intellectual freedom, which represent different phase of freedom influencing by education. The previous is the object while the latter is the goal.

Abstract freedom is ability to do what people please getting birth from people perceptual will. Hegel criticize and calls it impulses, desires, inclinations, which unfolds human nature as animal. In 
impulses, mind has not been liberated, on the contrary, ruled by nature. Perceptual will is the most fundamental character for animal. Animal has no choice but listen to the order of impulse for there is nothing to stop them. Natural freedom, as Hegel states, only enjoys infinity in form, which means it is constrained both in nature and reality. People who are wishing for that is an utter immaturity of thought, for it contains not even an inkling of the absolutely free will, of right, ethical life, and so forth [8]. Furthermore, in this condition, people believe that every institution and every organ of the state passes as a restriction on freedom of that kind, which is thought wrong by Hegel.

Education aims at pulling people out from the unfreedom. Education performances as a work which struggle against pure subjectivity of demeanor, against the immediacy of desire, against the empty subjectivity of feeling and the caprice of inclination [9] as it instills rules and teaches how to fight with perpetual impulse. Thus, for individual, education is the only way of gaining conditional freedom. Well-cultured people should control his action to enjoy intellectual freedom. True freedom should be stipulated, bound and rational. Finiteness is core to freedom, because only those who are ruled in all aspects can know himself as something infinite, universal, and free.

\subsection{Building Complete Self-consciousness}

When people finds out being free is his nature, he accomplishes pure consciousness to himself, development of body and mind, namely education in order to essentially through one's selfconsciousness's apprehension of itself as free. Reflection and possession of product of mind is the impact of individual education.

Reflection is the start of forming self-consciousness. That is to say, education should firstly breaks pure motion and origin nature. But how to realize that? Education offers a perspective for rethinking old though and cleaning obstacle for new thought. Hegel believes that with the help of reflect, Impulses would be purged in comparison and all the roughness and brutality would be abandoned. Reflection only occurs in education, for the value of education is to pushing mind forward from selfwill to reason. Specifically, "right" ideas inserted in education helps people jumping out of thinking inertia and observing mind. Honing mind gains the common growth in itself.

Education also helps people occupy his mind by spreading or creating product of mind, which result in the grown-up of self-consciousness. Firstly, people contact with ideas other than themselves' and then occupy. Hegel believes that people occupying of everything is an absolute right. They firstly get to mature product of mind produced by others, and make it the possession of their ideas, memory, and thinking. Product of mind is taken as article. As people learning knowledge, they transfer the will and idea into something concrete. When occupying the knowledge, they occupy themselves. Secondly, people try to express what they think, which results in the product of their own mind. Hegel stresses the importance of expression. By means of expression, people make the knowledge into a transferable article.

\subsection{Adjusting to the State's Ideas}

Unification of individual's idea and state's idea is the vital effect of individual education. Idea of the state theoretically manifests its nature. Hegel states that the state idea is the concrete Idea or the mind of nation, which has its own truth and discipline. In other words, the state's idea represents basic rule of mind development. Unity of thinking by education is inevitable.

By waking people's political sentiment, the only fundamental sense to hold the state together has been built. Fundamental sense here refers to individual's acceptation to state's idea, which means they have the same purpose. Hegel points out that it is political sentiment rather than power who maintain the ruling. [10]."

"The political sentiment, patriotism pure and simple, is assured conviction with truth as its basis

This represents trust to very idea of the state. People who has it believes deeply that the community is one's substantive groundwork and end.

Hegel predicts that people would have ideal mind----the state Idea, because it is the inner development of ideas. From the very beginning, people know the state as their substance. Therefore in education, idea of state becomes measurement criteria of truth. The learner would be confident that the state must subsist and that in it alone can particular interests be secured, but the faith is 
blinded by habit. Thus, what their whole existence depending on is invisible even though they really will it. Changing this habit is the mission of education. In this way the agreement to state idea could be increased and people would take it as the readiness for extraordinary exertions.

\section{Practicing of Education: Leading by the State}

\subsection{Practical Environment for Education}

"The rational end of man is life in the state [11]." This means the state has always been the environment of people's action, naturally of education. Pythagorean holds that the best way for children's ethical education is to make him a citizen of a state with good law. Hegel nods to this opinion and further expands it to civil education.

On the one hand, the nature of people has decided that education would not work out of the state. People born to be civil and their reaction born to be national. For Hegel, it is not simply saying that people should live in the state, moreover, people has fatal connection to the state. Beyond all question, all the social formation are walking towards form of the states. Out of management of the state, people can only live in the form of separation and formless, which leads to spontaneous, barbaric, unreasonable and horrific condition. From the perspective of individual, becoming a state member is the highest obligation and all the citizens have one and the same end, an absolute and permanent end is a huge progress of modern state.

On the other hand, classes and groups built in the state are the requirement for education. " $A$ man must be a 'somebody' [12]." Somebody here refers to a person belongs to a certain group, for example, an occupation or a social class. This is the necessity for realizing value of work in reality. The state, as practical environment, contains all kinds of classes, organizations and labor opportunities, which ensures every person could be somebody while practicing. Education in the state, which integrated in daily life, would directly equipped people with basic knowledge of interaction and skills of work so that they could be access to certain groups. Moreover, Hegel believes that education out of the state means nothing for it trial of separate people from law of would. Such as the Emile experiment of Rousseau, this kind of education are definitely a failure.

\subsection{Educating Content Deciding}

Content about freedom, will and self-consciousness are the core of education. However those are too abstract to be seen. Only when those truths are shown in more concrete objects including law, religion and morality, can they be propagated and accepted.

Firstly, morality reflects highest level of education. For one thing, it is the good in reality, and key for mind development. It appears as a living good in people's self-consciousness and knowledge hierarchy. Also, morality is a passive phase before ethic while still gains great acknowledgment by authority. In this phase, the good is something outside the mind and has to be "forced" or guided by morality education. Otherwise, people cannot consciously assimilates the idea of the good. By carrying out obligations, people forming the habitual practice of ethical living, which replaces the initial, purely natural will.

Secondly, education of law represents direct participation of the state. The state use law to restrain its people. While Hegel puts that this is not the nature of law. The real reason for law being a kind of public education is its connotation of free will. Normally, law in practice is an idea or knowledge. Repetition shows how the law education carries out, by which it means methods like teaching and infusing.

Thirdly, religion education works as emotional support. Hegel believes in belief. He calls the religion emotion of people the noblest sense, and this emotion raised naturally from the bottom of heart. Even though Hegel doesn't think the state could put its hand into religion education, he do recommends the state discharges a duty by affording every assistance and protection to the church in the furtherance of its religious ends, and should even require all its citizens to belong to a church. This is due to the nature of religion and also taken as civil obligation. Seemingly, the state tries to protect religion belief of civils. While truly religion education, just as law, become a member of mind educator. 


\subsection{Education Method Choosing}

People's education should be taken by certain organizations as well as approaches. Hegel chooses the state to judge this because of its authority. He points out that to educate people the state can offer both theoretical methods and practical methods.

Firstly, Hegel advocates establishing public educational institutions as official educating methods. One of its purpose is to complete the education of understanding in every way, namely the building up of language. They provides theories for communication, living and work. Taking in the public education would be a requirement of the nation. As a result, people gain a flexibility and rapidly of mind, ability to pass from one idea to another, to grasp complex and general relations. Another purpose is to train special ability of labor, including the so-called "science" of matters and necessary skills. In this training, people discover their different working destiny so that they can find their own group, which called by Hegel their way of finding class nature. The third purpose is to doing mind and ethical education so that the mechanical and semi-mechanical activity is removed, and habits of polite demeanor are cultivated.

Secondly, requiring all people taking part in working. Hegel believes that by finding balance between individual need and its need, the state ask people to work to satisfy themselves. The practical education can cultivate characters of endeavoring or some else required by the state. For example, characters of a deputy are the result of the actual transaction of business in managerial or official positions.

Thirdly, the state should publicize the Estates debates to provide approach to politic theory education. Hegel says that the publicity of Estates debates has distinguished pedagogical meaning to civil. Knowledge about political matters would be popularized. People would have open access to political affairs and take a glance of what the government do, therefore forms real public opinion and right political judgement. This is another antidote to the self-conceit of individuals singly and 'en masse', and another means -indeed one of the chief means -of their education ${ }^{[13]}$. Publicity is also the chief means of educating the public in national affairs.

\section{Summary}

Hegel has talked about the noble character and the ambitious goal of education and defined it the fundamental method of mind liberation. However, his statement is incompatible with Marxist historical materialism. Making the state idea the criteria of education has changed the meaning of education. Education is more a tool for ruling class rather than property for people. Therefore, Hegel's education idea doesn't teach people how to respect mind, instead it makes people more restricted to mind, which resulting in less freedom. Hegel makes every effort to touch the nature of education but still restricted by conservative class ideology. Looking into Hegel's "education" from the perspective of historical materialism would deepen the understanding of Marx's critique towards Hegel's Philosophy of Right.

\section{References}

[1]. T.M. Knox (translated with notes). HEGEL'S Philosophy of Right. Oxford University Press, 1952, p.125.

[2]. T.M. Knox (translated with notes). HEGEL'S Philosophy of Right. Oxford University Press, 1952, p. 128

[3]. T.M. Knox (translated with notes). HEGEL'S Philosophy of Right. Oxford University Press, 1952 , p.67

[4]. T.M. Knox (translated with notes). HEGEL'S Philosophy of Right. Oxford University Press, 1952 , p.260 
[5]. T.M. Knox (translated with notes). HEGEL'S Philosophy of Right. Oxford University Press, 1952, p.108

[6]. T.M. Knox (translated with notes). HEGEL'S Philosophy of Right. Oxford University Press, 1952, p.129

[7]. T.M. Knox (translated with notes). HEGEL'S Philosophy of Right. Oxford University Press, 1952, p.196

[8]. T.M. Knox (translated with notes). HEGEL'S Philosophy of Right. Oxford University Press, 1952, p.27

[9]. T.M. Knox (translated with notes). HEGEL'S Philosophy of Right. Oxford University Press, 1952, p. 125

[10]. T.M. Knox (translated with notes). HEGEL'S Philosophy of Right. Oxford University Press, 1952, p.163

[11]. T.M. Knox (translated with notes). HEGEL'S Philosophy of Right. Oxford University Press, 1952 , p. 242

[12]. T.M. Knox (translated with notes). HEGEL'S Philosophy of Right. Oxford University Press, 1952 , p. 271

[13]. T.M. Knox (translated with notes). HEGEL'S Philosophy of Right. Oxford University Press, 1952, p.204 